\title{
Growth, yield and post-harvest evaluation of lettuce plants subjected to different leaf silicon concentrations
}

\section{Myriam Galvão Neves ${ }^{1}$, Mário Lopes da Silva Júnior ${ }^{1}$, Candido Ferreira de Oliveira Neto ${ }^{1}$, Ricardo Shigueru Okumura ${ }^{2}$, Gerson Diego Pamplona Albuquerque ${ }^{1}$, Tiago de Souza Santiago ${ }^{3}$}

\author{
${ }^{1}$ Universidade Federal Rural da Amazônia, Campus Belém, Belém, Pará, Brasil. E-mail: agronomyriam@hotmail.com, \\ mario.silva@ufra.edu.br, candido.neto@ufra.edu.br, gersoncorel@hotmail.com \\ ${ }^{2}$ Universidade Federal Rural da Amazônia, Campus Parauapebas, Parauapebas, Pará, Brasil. E-mail: ricardo.okumura@ufra.edu.br \\ ${ }^{3}$ Universidade Federal do Piauí, Campus Bom Jesus, Bom Jesus, Piauí, Brasil. E-mail: tiagosantiago1415@gmail.com
}

Received: 01/03/2020; Accepted: 14/08/2020.

\begin{abstract}
Lettuce is considered the most produced and consumed leafy vegetable; however, it has short post-harvest life, which generates significant losses for both producers and consumers. Studies have proven the beneficial effect of silicon on fruits and vegetables. Therefore, the aim of the current study is to evaluate the influence of leaf calcium silicate application on the growth, biomass production and postharvest conservation of curly lettuce. The experiment was carried out in greenhouse at Federal Rural University of Amazonia, Parauapebas Campus / PA. It followed a completely randomized design (CRD) with five Si concentrations (0.0, 2.0, 4.0, 6.0 and 8.0 mg L-1) and eight repetitions, which totaled 40 plants. Plants were grown in plastic pots (capacity $=3 \mathrm{dm}^{3}$ ) filled with soil classified as Red-Yellow Argisol. Different Si concentrations were applied to plant leaves, at the $20^{\text {th }}$ and $27^{\text {th }}$ days after transplantation (DAT). Silicon has favored the growth and development of lettuce plants, as well as reduced their post-harvest weight loss. It was possible concluding that the herein tested Si concentrations, which were applied to leaves - in the form of calcium silicate - had beneficial effect on lettuce plants.
\end{abstract}

Keywords: Lactuca sativa L., beneficial element, vegetable, mineral nutrition of plants, growth analysis.

\section{Crescimento, produção e avaliação pós-colheita em plantas de alface submetidas a concentrações de silício foliar}

\section{RESUMO}

A alface é considerada a hortaliça folhosa mais produzida e consumida, porém, apresenta vida pós-colheita curta, gerando assim muitas perdas e prejuízos ao produtor e ao consumidor. Estudos têm comprovado o efeito benéfico do silício em frutas e hortaliças. Diante disso, o objetivo foi avaliar a influência da aplicação foliar de silicato de cálcio no crescimento, produção de biomassa e conservação pós-colheita de alface crespa. O experimento foi desenvolvido em casa de vegetação na Universidade Federal Rural da Amazônia, campus de Parauapebas/PA. Utilizou-se o delineamento inteiramente casualizado (DIC) com cinco concentrações de $\mathrm{Si}(0,0 ; 2,0 ; 4,0 ; 6,0$ e 8,0 $\mathrm{mg} \mathrm{L}^{-1}$ ) e oito repetições, totalizando 40 plantas. As plantas foram conduzidas em vasos plásticos com capacidade para $3 \mathrm{dm}^{3}$, contendo solo classificado como Argissolo Vermelho-Amarelo. As concentrações de Si foram aplicadas via foliar, aos 20 e 27 dias após o transplantio (DAT). O silício favoreceu o crescimento e desenvolvimento das plantas de alface e reduziu também a perda de massa pós-colheita. Concluiu-se que nas concentrações testadas há efeito benéfico do silício na forma de silicato de cálcio via aplicação foliar em plantas de alface.

Palavras-chave: Lactuca sativa L., elemento benéfico, hortaliça, nutrição mineral de plantas, análise de crescimento. 


\section{Introduction}

Lettuce (Lactuca sativa L.) is a leafy vegetable belonging to family Asteraceae. Although it derives from wild species found in the Mediterranean region, which presents temperate climate, it is grown worldwide. It is often consumed in salads and as ingredient in sandwiches. Given its origin in temperate climate regions, some cultivars were successfully developed and adapted to tropical conditions (Sala and Costa, 2012; Aquino et al., 2014).

It is the most important leafy vegetable produced in Brazil, since it has economic and social importance for the country. It is often consumed in natura in order to preserve its nutritional properties, such as vitamin A and mineral salts (Freitas et al., 2013).

Despite its commercial and consumption importance, lettuce is highly perishable after harvest, since it is mostly composed of water, a fact that limits its cultivation close to consumer centers, the so-called "green belts" of large cities (Azevedo et al., 2015).

Lettuce deterioration starts at harvest time, a fact that often results in poor appearance and quality products. Therefore, great care must be taken to assure quality products to end consumers and traders, since the consumer market increasingly demands quality and good-looking products (Antoniali et al., 2009).

Studies have investigated the use of silicate fertilization as alternative to prolong the post-harvest conservation of fruits and vegetables. It is so, because Silicon ( $\mathrm{Si}$ ) is capable of protecting vegetables by accumulating in the cuticle of leaves to help reducing water loss, increasing plants' photosynthetic capacity and promoting greater plant growth (Galati et al., 2015).

Silicon ( $\mathrm{Si}$ ) is the second most abundant element in Earth's crust; it is found in tropical soils in the form of opal and quartz $\left(\mathrm{SiO}_{2} \mathrm{nH}_{2} \mathrm{O}\right)$ and is absorbed by plants in the form of monosilicic acid $\left(\mathrm{H}_{4} \mathrm{SiO}_{4}\right)$ together with water; leaves are the main $\mathrm{Si}$ depository organ (Korndörfer, 2017). In addition to the soil, silicates are the main $\mathrm{Si}$ sources and have a series of beneficial functions; among the used materials, one finds steel slag, wollastonite, by-products deriving elemental phosphorus production, calcium metasilicate, sodium metasilicate, cement, thermophosphate, magnesium silicate and calcium silicate (Demattê et al., 2011). Sodium metasilicate and calcium silicate stand out among Si sources commercially used in agriculture (preferably in hydroponic studies and in leaf applications, due to its high solubility).

The use of Silicon in agriculture is clean and sustainable, since it helps reducing the application of pesticides and maximizing crop yield based on better balanced and physiologically more efficient plant nutrition. This process leads to more productive, healthy and vigorous plants, mainly due to pest attack and disease mitigation (Lima Filho, 2013).

In addition, $\mathrm{Si}$ plays a key role in collagen biosynthesis and in human bone tissue formation and calcification processes. It is also associated with calcium contents in the human body and is causally linked to individuals' age; thus, Si deficiency leads to increased susceptibility to diseases. Therefore, it is essential consuming food rich in $\mathrm{Si}$; the consumption of vegetables such as lettuce is one of the alternatives used to meet this need in human diet (Sripanyakorn et al., 2005).

Recent studies have shown considerable results for this element in agriculture; among them, one finds increased yield in several crops, improvements in unfavorable physicochemical, physical and chemical soil conditions, improved plant resistance to pests and diseases due to better plant nutrition, as well as beneficial results in biotic and abiotic stress relief. Therefore, $\mathrm{Si}$ is a viable alternative to help improving plant development (Gonzalo et al., 2013; Hernandez-Apaolaza, 2014).

The structural function of $\mathrm{Si}$ in cell walls is associated with high hemicellulose and lignin contents capable of increasing cell rigidity, of improving the final quality of plants and, consequently, of increasing lettuce leaf firmness, which, in its turn, reduces water loss in the post-harvest period and prolongs lettuce's shelf life (Epstein, 1999; Barbosa Filho et al., 2001).

Lettuce is one of the leafy vegetables presenting low $\mathrm{Si}$ absorption, the so-called non-accumulator plants. Therefore, leaf $\mathrm{Si}$ application can enable greater accumulation of it in leaf tissues (Marschner, 1995) and help prolonging their useful life by reducing water loss during storage.

The importance of silicate fertilization has been confirmed in studies conducted with leafy vegetables. However, it is necessary collecting further information about the effect of this element and the ideal dose of it capable of increasing lettuce yield and improving postharvest conservation.

Galati et al. (2015) have investigated the effect of silicon application to hydroponic vegetables, at concentrations of $0,28,56$ and $84 \mathrm{mg} \mathrm{L}^{-1}$, on the postharvest conservation of minimally processed 'Lucy Brown' lettuce. Results have shown that Si concentration of $84 \mathrm{mg} \mathrm{L}^{-1}$ provided greater firmness to the leaves of minimally processed lettuce plants, a fact that made them more turgid and enabled maintaining their useful life for 16 days.

Pohlmann et al. (2018) have investigated the effect of silicate fertilization on the yield and visual quality of arugula plants subjected to the application of $0.00,0.03$, $0.07,0.10,0.13$ and $0.17 \mathrm{~g}$ of $\mathrm{Si}_{\text {plant }}{ }^{-1}$. Results have shown that $\mathrm{Si}$ doses applied to the leaves of arugula cultivar conducted in greenhouse environment have 
affected plant height, root length, number of plants, shoot dry phytomass, as well as root fresh and dry phytomass.

Studies have also shown that several crops presented higher yield after they were subjected to silicate fertilization. Zanão Júnior et al. (2013) have conducted a study with roses grown in pots and observed that $\mathrm{Si}$ application in the substrate has increased the rose yield and improved their quality - outcomes have changed depending on Si concentrations and on the investigated cultivar.

Studies carried out with grass plants have also shown yield gains after they were properly supplied with $\mathrm{Si}$. According to Dantas Júnior et al. (2013), calcium and magnesium silicate application have positively affected maize grain yield, which recorded higher rates. Lack of further information about the action of this micronutrient in vegetables justifies the present study, whose aim was to investigate the effect of leaf application of increasing calcium silicate concentrations on the growth, biomass production and postharvest conservation of curly lettuce.

\section{Material and Methods}

The study was carried out in a greenhouse at Federal Rural University of the Amazonia (UFRA), Parauapebas County, Pará State, from November 2018 to January 2019 ; it covered the period from $11 / 23^{\text {rd }} / 2018$ (sowing) to $01 / 09^{\text {th }} / 2019$ (last post-harvest evaluation). According to the Köppen's classification, the climate in the region fits into the super humid equatorial category (Am type) at the transition limit to Aw. It presents mean annual temperature of $26.35^{\circ} \mathrm{C}$, with two well-defined seasons; the dry season goes from June to October, whereas the rainy season goes from November to May. Mean relative humidity is $78 \%$, with annual rainfall index of approximately 2,000 mm (Pará, 2012).

The experiment was conducted with curly lettuce variety SRV 06511236 (Solaris) and it aimed at investigating its response to silicate fertilization. Seedlings used in the experiment were purchased from a producer in the region; 40 lettuce seedlings showing the same size and age pattern were selected and transplanted into pots when they were $8 \mathrm{~cm}$ tall.

Plastic pots with $3 \mathrm{dm}^{-3}$ soil capacity were planted with single plant, each. The adopted substrate consisted of Red-yellow Argisol collected at the $0-20 \mathrm{~cm}$ soil layer in the UFRA Agroforestry System Sector (Santos et al., 2013). Soil samples were collected at the same site and layer the soil used as substrate was removed from and sent to the laboratory for chemical analysis.

Collected soil samples were dried, sieved (4 mm mesh) and homogenized. Next, a fraction of these samples was taken and subjected to chemical and granulometric analysis in order to determine soil fertility and texture.
Fertilization was carried out according to recommendations by Yuri et al. (2016) for lettuce culture. All plants were subjected to fertilization at the following concentrations: $100 \mathrm{mg}$ of nitrogen, $200 \mathrm{mg}$ of potassium and 2,083 $\mathrm{mg}$ of phosphorus per pot. Nitrogen was applied in three installments. The first application was carried out seven days after seedlings were transplanted into the pots, and the other two were carried out at 10day intervals between fertilizations. Urea, potassium chloride and simple superphosphate fertilizers were used as source of nitrogen, potassium and phosphorus, respectively.

Plants remained healthy throughout the experimental period; thus, it was not necessary making any intervention to control pests and diseases. Irrigation was manually done, based on the mean application of $200 \mathrm{~mL}$ of water/plant/day, split between the morning and afternoon shifts, according to plants' needs.

Tests were carried out in greenhouse by assuming homogeneous experimental conditions. They followed a completely randomized design (CRD) with five $\mathrm{Si}$ concentrations $\left(0.0,2.0,4.0,6.0\right.$ and $\left.8.0 \mathrm{mg} \mathrm{L}^{-1}\right)$ and eight repetitions, which totaled 40 plants; calcium silicate $\left(88 \% \quad \mathrm{SiO}_{2}\right)$ was the silicon source used in the experiments. The adopted Si concentrations were applied to plant leaves; the first application was performed 20 days after seedling transplantation, whereas the second application was carried out 7 days after the first one.

Leaf fertilizer application was carried out with the aid of a manual sprayer (volume of $50 \mathrm{~mL}$ of syrup per plant) at intervals of 20 and 27 DAT from one spray to the other, respectively (Figure 1). These intervals were estimated based on the culture cycle, which often ranges from 35 to 40 DAP. Vegetables were harvested 10 days after the last fertilizer application, in a total cycle of 37 days. The $\mathrm{pH}$ value recorded for the syrup added with $\mathrm{Si}$ was 6.7 in both sources; corrections were carried out with $\mathrm{HCl}$ (1.0 mol L-1) or $\mathrm{NaOH}\left(1.0 \mathrm{~mol} \mathrm{~L}^{-1}\right)$ solution. Spraying was performed on plant shoot after 05:00 p.m.

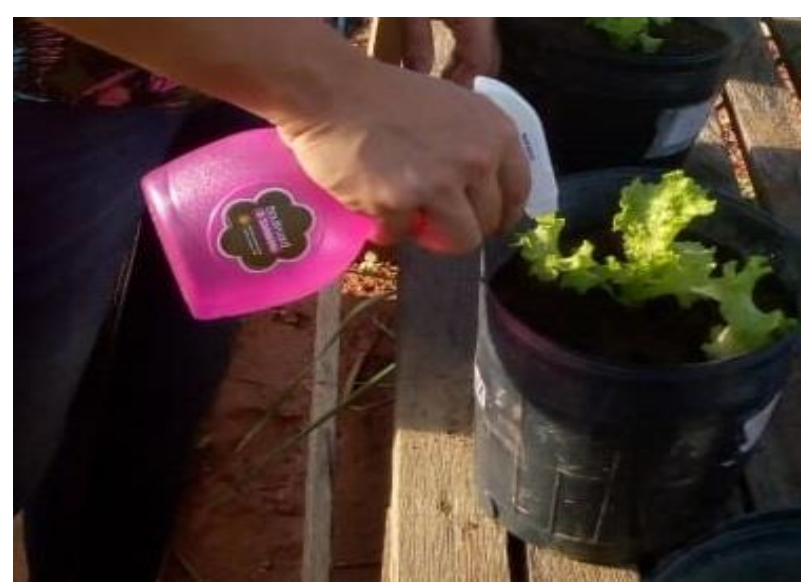

Figure 1. Leaf application of calcium silicate in lettuce plants. Parauapebas, PA, 2019. 
Side barriers were used during $\mathrm{Si}$ applications on plants' leaves to avoid pot contamination via air and to assure better application efficiency, since droplets dissipate in the air at spraying time and can cause unwanted contamination from other sources.

Plants subjected to treatment with calcium silicate have shown satisfactory development until the end of harvest (Figure 2).

Harvest was performed when senescence signs were observed on basal leaves, at the $37^{\text {th }}$ day after transplantation (Figure 3). Eight plants from each treatment were collected and separated into shoot and root in order to determine the following aspects: root length (RL), number of leaves per plant (NLP), stem fresh mass (SFM), leaf fresh mass (LFM), shoot fresh weight (SFW) and root fresh weight (RFW).

Plants were taken to the soil laboratory where they were weighed on digital scale and the number of leaves per lettuce plant was counted. Next, plant shoot and root were separated from each other; roots had their length measured with the aid of graduated ruler (Figure 4) and were weighed to determine root fresh mass. Subsequently, all plants were washed (in separate) in running water, rinsed with distilled water and placed in properly identified paper bags.

All materials were transferred to forced air circulation oven at $65^{\circ} \mathrm{C}$, where they remained until constant weight was reached; results were expressed in grams. After the drying process was over, the dry mass of each plant was determined.

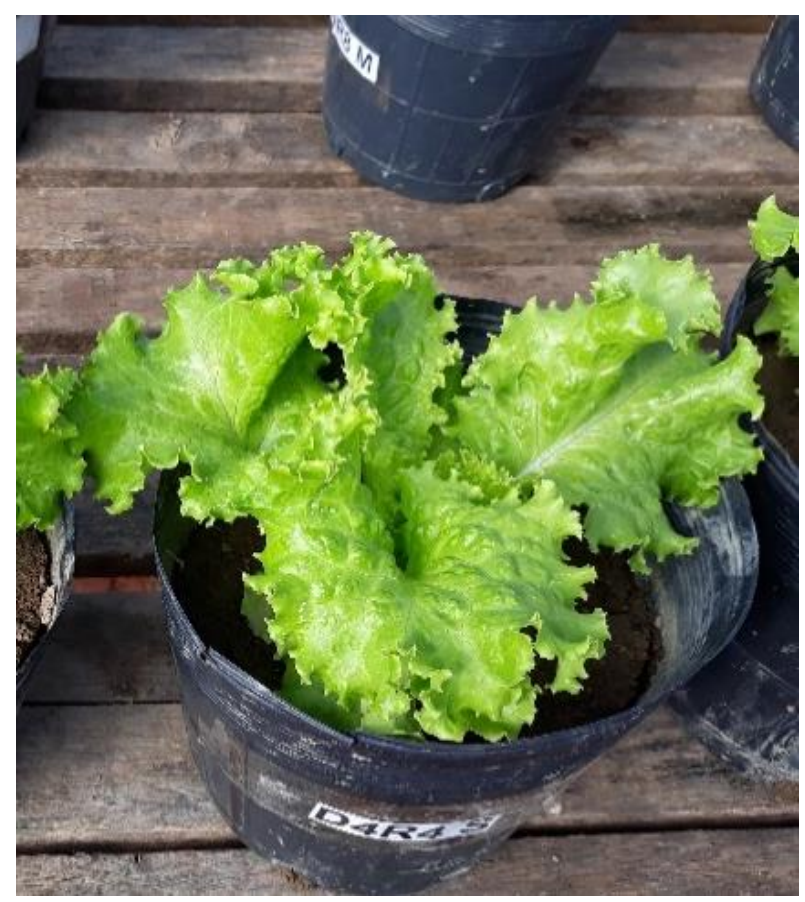

Figure 2. Lettuce plants treated with calcium silicate at 20 DAT. Parauapebas, PA, 2019.

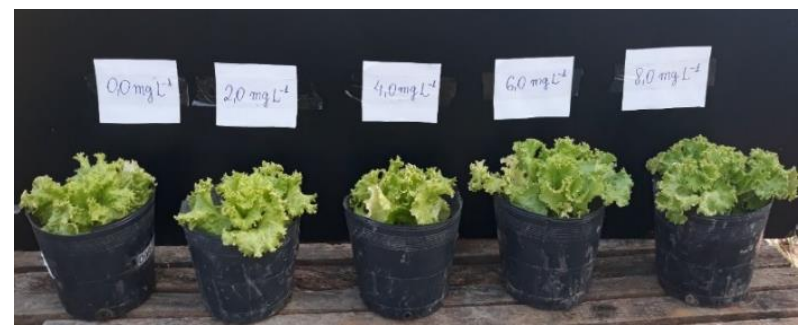

Figure 3. Lettuce plants treated with calcium silicate $(0.0,2.0$, 4.0, 6.0 and $8.0 \mathrm{mg} \mathrm{L}^{-1}$ ). Parauapebas, PA, 2019.

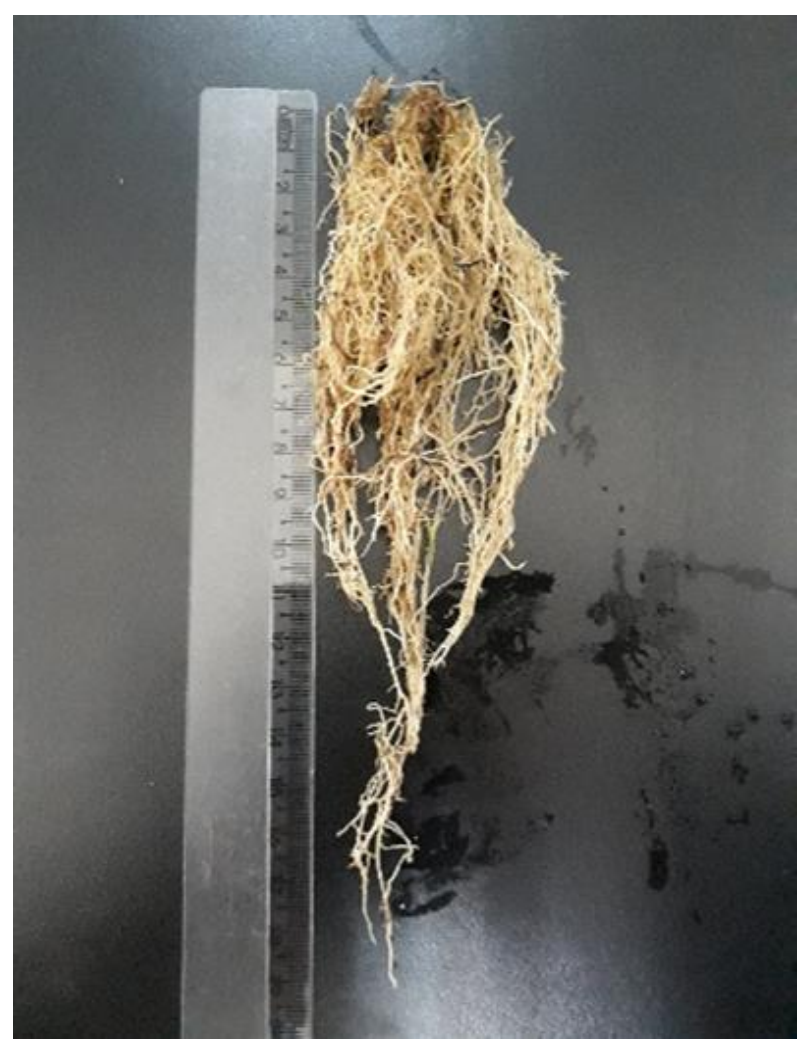

Figure 4. Root length of lettuce plants subjected to leaf treatment with calcium silicate $\left(0.0,2.0,4.0,6.0\right.$ and $\left.8.0 \mathrm{mg} \mathrm{L}^{-1}\right)$. Parauapebas, PA, 2019.

Plants were collected 37 days after transplantation, weighed on precision scale and stored in plastic bags under refrigeration conditions; they were weighed every five days and subjected to post-harvest evaluations until they got unfit for trading. Data were subjected to regression analysis based on different calcium silicate concentrations applied to lettuce plants. The formula suggested by Chitarra and Chitarra (2005) was used to determine mass loss:

$$
\operatorname{ML}(\%)=\frac{\mathrm{Wi}-\mathrm{Wj}}{\mathrm{Wi}} * 100
$$

Wherein:

$\mathrm{ML}=$ mass loss $(\%)$,

$\mathrm{Wi}=$ initial weight,

$\mathrm{Wj}=$ weight in the period following $\mathrm{Wi}(\mathrm{g})$. 


\section{Results and Discussion}

Values recorded for mean root length (Figure 5A) were adjusted through linear equation $\left(\mathrm{R}^{2}=0.95\right)$; they have indicated shorter root length in response to increased $\mathrm{Si}$ concentration, i.e., the longest length was recorded in lack of silicon source. Therefore, it is possible inferring that increased calcium silicate concentrations have led to shorter root length in lettuce plants.

The current results differ from the ones recorded by Pohlmann et al. (2018), who investigated the effect of silicate fertilization $(0.00,0.03,0.07,0.10,0.13$, and $0.17 \mathrm{~g} \mathrm{Si}$ plant $^{-1}$ ) on the yield and visual quality of arugula plants, which presented longer root length after silicate fertilization.

Shorter root length may be explained by the fact that the excessive absorption of a certain nutrient can cause nutritional imbalance and affect the absorption of some essential nutrients for lettuce plants. Therefore, it is important taking into consideration nutrients as a whole at the time to analyze mineral nutrition, since one nutrient may influence the other during nutrient absorption processes due to likely interactions that may take place (Malavolta et al., 1997).

Increased $\mathrm{Si}$ concentrations applied to lettuce leaves has increased the number of leaves per plant, at linear adjustment $\left(\mathrm{R}^{2}=0.98\right)$, as shown in Figure 5B. Such an increase is associated with the fact that Si spraying on lettuce leaves has increased its amount in these plants; with silicon deposition and polymerization on cell wall, which may have favored physiological variables reported by several authors; as well as with the fact that leaves are the main deposition organ of these plants (Takahashi and Kurata, 2007).

The current results differ from the ones reported by Curvelo et al. (2019), who assessed the effects of silicate fertilization (0, 20.0, 30.0 and $40.0 \mathrm{mg} \mathrm{L}^{-1}$ of silicon) on the postharvest quality and yield of Sharon cauliflower cultivar.

Variables such as stem fresh and dry mass (Figures $5 \mathrm{C}, 5 \mathrm{D})$ have adjusted to the linear equation model $\left(\mathrm{R}^{2}=\right.$ $0.76)$ and $\left(R^{2}=0.85\right)$, respectively. Silicon has led to increase in these variables, although most absorbed $\mathrm{Si}$ deposition takes place in plants' leaves $(71 \%$ of the total deposition) and stem (13\% of the total deposition) (Yoshida, 1975).

The current results corroborate the ones reported by Resende et al. (2003), who investigated the influence of five different silicon concentrations $(0.0,0.9,1.8,2.7$ and $3.6 \mathrm{~kg} / \mathrm{ha})$, applied at three different times via leaf (14, 21 and 28 days after transplantation), on the yield and quality of lettuce species Lactuca sativa L. and did not observe increase in these variables.

In addition, $\mathrm{Si}$ application has positively influenced leaf fresh and dry masses (Figures 5E, 5F). Such an increase is associated with the role played by silicon in increasing hemicellulose and lignin contents in leaves, which leads to increased plant cell rigidity (Barbosa Filho et al., 2001).

These results corroborate the ones reported by Guerrero et al. (2011), who applied Si concentrations of $0,0.075,0.150,0.225$ and $0.300 \mathrm{~mL} /$ pot to arugula leaves and did not find influence of these concentrations on leaf fresh and dry mass values.

Leaf Si application has linearly increased $\left(\mathrm{R}^{2}=0.94\right)$ shoot fresh mass production (Figure 6A). The increased shoot fresh mass may be associated with increased number of lettuce leaves, which was also enabled by leaf Si application (Figure 5B). This finding indicates that small silicon concentrations are beneficial for plant turgidity, since they keep them turgid and erect and, consequently, enable longer shelf life.

The current results are in compliance with the ones reported by Galati et al. (2015), who observed linear increase in the shoot fresh mass of lettuce plants as the $\mathrm{Si}$ in the nutrient solution increased. Lettuce plants subjected to silicon concentration of $84 \mathrm{mg} \mathrm{L}^{-1}$ recorded shoot fresh mass of $493.2 \mathrm{~g}$.

Plants subjected to leaf $\mathrm{Si}$ applications recorded higher shoot dry mass than the control. It may have happened due to $\mathrm{Si}$ accumulation in leaves since it tends to accumulate in this organ (Figure 6B). The increased shoot dry mass can also be explained by $\mathrm{Si}$ effects on growth variables such as number of leaves $\left(\mathrm{R}^{2}=0.98\right)$ and shoot fresh mass $\left(\mathrm{R}^{2}=0.94\right)$.

The current results meet the ones reported by Souza et al. (2015), who evaluated the response (i.e., commercial shoot dry matter production and macronutrient accumulation) of lettuce cv. Vera subjected to the application of different nitrogen and leaf potassium silicate-based fertilizer concentrations (1.15, $6.90,11.50,16.10$ and $21.85 \mathrm{~kg} \mathrm{ha}^{-1}$ ). The use of leaf Si at the dose of $21.85 \mathrm{~kg} \mathrm{ha}^{-1}$ in lettuce plants has increased dry matter weight by $102 \%$.

Means recorded for root fresh and dry mass (Figures $6 \mathrm{C}$ and $6 \mathrm{D})$ have adjusted through linear equation $\left(\mathrm{R}^{2}=\right.$ $0.91)$ and $\left(R^{2}=0.96\right)$, respectively. There two variables were positively influenced by $\mathrm{Si}$ i.e., increased $\mathrm{Si}$ concentrations have favored root production, although the application of this element was carried out via leaf and its deposition often takes place in leaf tissues, stem support and, at lower concentrations, in roots, where it was possible observing this increase, which proved the efficiency of this element (Elawad and Green Junior, 2012).

Similar results were reported by Pohlmann et al. (2018), who investigated the effect of silicate fertilization (at the concentrations of 0.00, 0.03, 0.07, 0.10, 0.13 and $0.17 \mathrm{~g} \mathrm{Si} \mathrm{plant}^{-1}$ ) on arugula yield and visual quality; they found significant difference in the analyzed variables. 

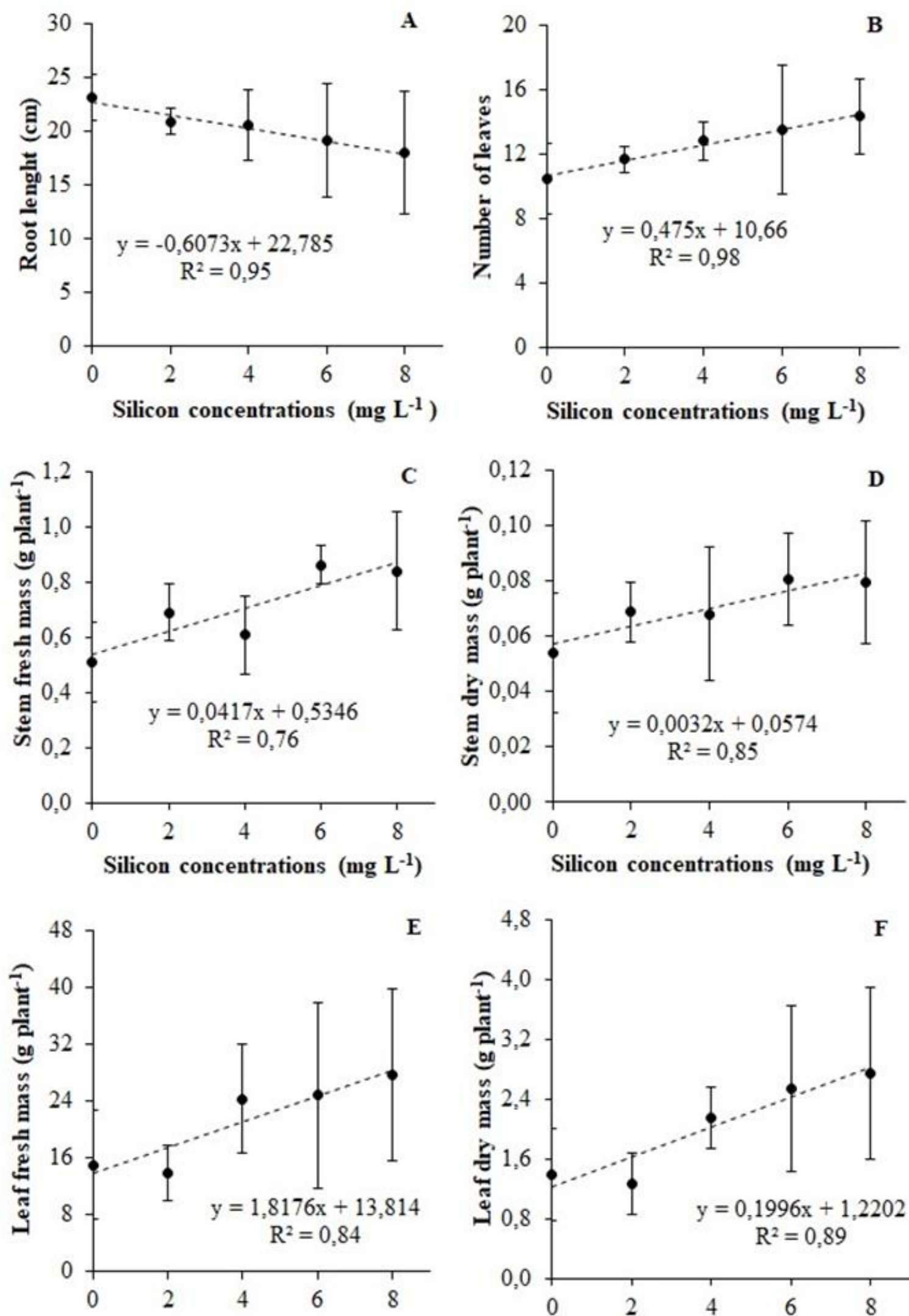

Silicon concentrations $\left(\mathrm{mg} \mathrm{L}^{-1}\right)$

Silicon concentrations $\left(\mathrm{mg} \mathrm{L}^{-1}\right)$

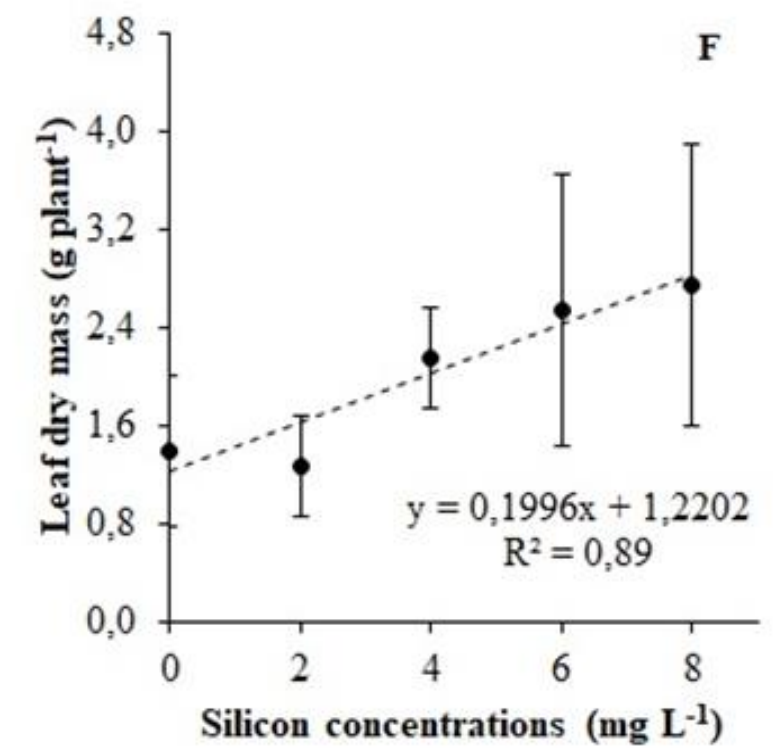

Figure 5. Root length (A), number of leaves (B), stem fresh mass (C), stem dry mass (D), leaf fresh mass (E), leaf dry mass (F) of lettuce plants subjected to leaf application of silicon concentrations ranging from 0.0 to $8.0 \mathrm{mg} \mathrm{L}^{-1}$. Parauapebas, PA, 2019 . 

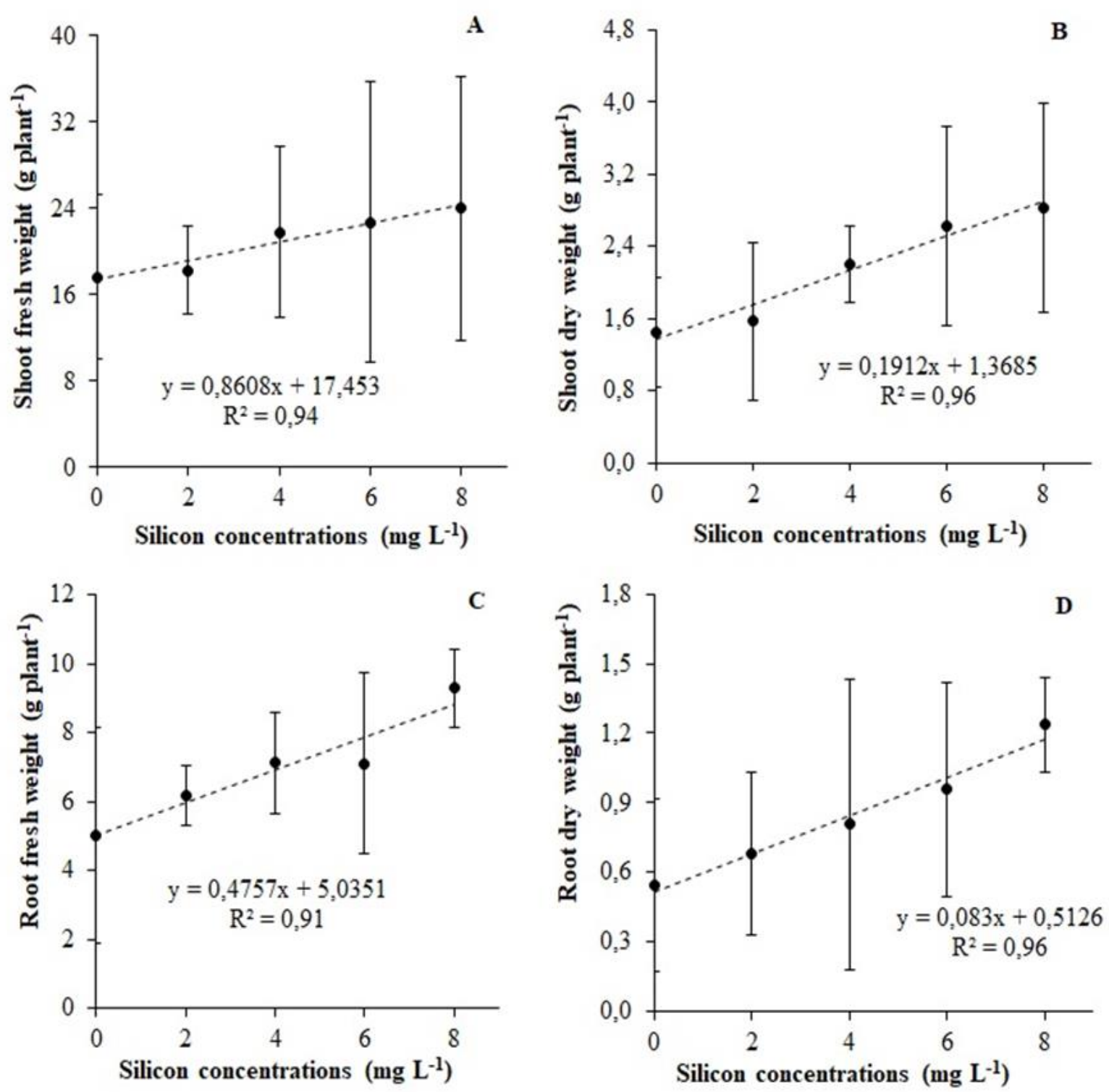

Figure 6. Shoot fresh weight (A), shoot dry weight (B), root fresh weight (C), root dry weight (D) of lettuce plants subjected to leaf application of silicon concentrations ranging from 0.0 to $8.0 \mathrm{mgL}-1$. Parauapebas, PA, 2019.

Mass loss (Table 1) has decreased as leaf $\mathrm{Si}$ concentrations increased. Si dose of $4.0 \mathrm{mg} \mathrm{L}^{-1}$ recorded the lower mass loss, whereas $\mathrm{Si}$ dose of $2.0 \mathrm{mg} \mathrm{L}^{-1}$ recorded the higher mass loss during storage (37, 42 and 47 days after harvest). The aforementioned mass loss is explained by the fact that plants absorbing $\mathrm{Si}$ form heavier polysilicic acid chains, which lead to polymerization. Consequently, stomata walls become less flexible, which leads to stomatal closure and reduces perspiration during water and mass loss. This process increases the useful life of lettuce plants since water loss is one of the factors leading to shorter post-harvest life of fruits and vegetables, as well as to poor quality and appearance products (Taiz et al., 2015).

Miranda et al. (2018) have investigated the potential use of silicon via leaf application in the integrated management of cabbage moth in cabbage plants and its postharvest effect. They have also observed lesser water loss in cabbage plants ( $8 \%$ throughout the storage period) subjected to treatment with Sil-K and agroSilicon.

Therefore, it is possible stating that leaf Si spraying helps reducing the water loss in leaves, which is a valuable information about leafy vegetables presenting short shelf life. 
Table. 1. Postharvest mass loss in lettuce plants based on leaf application of different calcium silicate concentrations $\left(\mathrm{Ca}_{2} \mathrm{SiO}_{4} \mathrm{mg} \mathrm{L}^{-1}\right)$. Parauapebas, PA, 2019.

\begin{tabular}{cccc}
\hline & & \multicolumn{2}{c}{ Days after planting } \\
\cline { 2 - 3 } $\mathrm{Ca}_{2} \mathrm{SiO}_{4}$ & & 42 & \multicolumn{2}{c}{47} \\
\cline { 2 - 3 } concentration $(\mathrm{mM})$ & & Mass loss (\%) \\
\hline 0 & 7,46 & 10,26 \\
2 & 15,34 & 26,74 \\
4 & 3,29 & 7,69 \\
6 & 8,73 & 11,17 \\
8 & 4,96 & 11,73 \\
\hline Mean & 7,96 & 13,52 \\
\hline
\end{tabular}

\section{Conclusions}

Based on results recorded in the present study, it is recommended using calcium silicate source via leaf application in lettuce plants since it was capable of increasing biomass production in the culture, enabled plant growth and development, as well as reduced mass loss during the postharvest plant conservation period plants subjected to the application of calcium silicate concentration of $4 \mathrm{mg} \mathrm{L}^{-1}$ was the ones presenting the lowest mass loss.

\section{Bibliographic References}

Antoniali, S., Sanches, J., Nachiluk, K., 2009. Mais alimentos ou menos perdas? http://www.aptaregional.sp.gov.br/artigo.php?id_artigo=623 (acessado 21 de dezembro de 2019).

Aquino, C.R., Seabra Junior, S., Camili, E.C., Diamante, M.S., Pinto, E.S.C., 2014. Produção e tolerância ao pendoamento de alface-romana em diferentes ambientes. Revista Ceres, 61(4), 558-566. DOI: https://doi.org/10.1590/0034737X201461040016.

Azevedo, A.M., Andrade Júnior, V.C., Pedrosa, C.E., Oliveira, C.M., Dornas, M.F.S., Valadares, N.R., 2015. Agrupamento multivariado de curvas na seleção de cultivares de alface quanto à conservação pós-colheita. Horticultura Brasileira, 33(3), 362$367 . \quad$ DOI: https://doi.org/10.1590/S0102053620150000300014 .

Barbosa Filho, M.P., Snyder, G.H., Fageria, N.K., Datnoff, L.E., Silva, O.F., 2001. Silicato de cálcio como fonte de silício para o arroz de sequeiro. Revista Brasileira de Ciências do Solo, 25(2), 325-330. DOI: https://doi.org/10.1590/S010006832001000200009 .

Chitarra, M.I.F., Chitarra, A.B., 2005. Pós-colheita de frutos e hortaliças: fisiologia e manuseio, segunda ed. Lavras, FAEPE.

Curvelo, C.R.S., Fernandes, E.F., Diniz, L.H.B., Pereira, A.I.A., 2019. Desempenho agronômico da couve-flor (Brassica oleracea var.botrytis) em função da adubação silicatada. Revista de Agricultura Neotropical, 6(1), 87-91. DOI: https://doi.org/10.32404/rean.v6i1.2556.

Dantas Júnior, E.E., Chaves, L.H.G., Costa, F.A.M., 2013. Silicate fertilizer and irrigation depth in corn production. Revista Ceres, 60 (4), 563-568. DOI: https://doi.org/10.1590/S0034-737X2013000400016.
Demattê, J.L.I., Paggiaro, C.M., Beltrame, J.A., Ribeiro, S.S., 2011. Uso de silicatos em cana-de-açúcar. Informações Agronômicas, $133, \quad 7-12 . \quad$ DOI: http://www.ipni.net/PUBLICATION/IA-

BRASIL.NSF/0/CF832453F89BC9D483257A8F005F59AE/\$ FILE/Page7-12-133.pdf.

Elawad, S.H., Green Junior, V.E., 1979. Silicon and the rice plant environment: a review of recent research. Revista IL RISO, 28(3), 235-253.

Epstein, E., 1999. Silicon. Annual Review of Plant Physiology and Molecular Biology, 50, 641-664. DOI: 10.1146/annurev.arplant.50.1.641.

Freitas, G.A., Silva, R.R., Barros, H.B., Melo, A.V., Abrahão, W.A.P., 2013. Produção de mudas de alface em função de diferentes combinações de substratos. Revista Ciência $\begin{array}{llll}\text { Agronômica, } & 44(1), & 159-166 . & \text { DOI: }\end{array}$ https://doi.org/10.1590/S1806-66902013000100020.

Galati, V.C., Guimarães, J.E.R., Marques, K.M., Fernandes, J.D.R., Filho, A.B.C., Mattiuz, B., 2015. Aplicação de silício, em hidroponia, na conservação pós-colheita de alface americana 'Lucy Brown' minimamente processada. Ciência Rural, 45(11), 1932-1938. DOI: https://doi.org/10.1590/0103$8478 \mathrm{cr} 20140334$.

Gonzalo, M.J., Lucena, J.J., Hernández-Apaolaza, L., 2013. Effect of silicon addition on soybean (Glycine max) and cucumber (Cucumis sativus) plants grown under iron deficiency. Plant Physiology and Biochemistry, 70, 455-461. DOI: https://doi.org/10.1016/j.plaphy.2013.06.007.

Guerrero, A.C., Borges, L.S., Fernandes, D.M., 2011. Efeito da aplicação foliar de silício em rúcula cultivada em dois tipos de solos. Bioscience Journal, 27(4), 160-170. DOI: http://www.seer.ufu.br/index.php/biosciencejournal/article/vie w/8246.

Hernandez-Apaolaza, L., 2014. Can silicon partially alleviate micronutrient deficiency in plants? A review. Planta, 240(3), 447-458. DOI: https://doi.org/10.1007/s00425-014-2119-x.

Korndörfer, G.H., 2017. Uso do Silício na agricultura. http://www.dpv24.iciag.ufu.br/Silicio/Efeitos/Efeitos.htm (acessado 15 de janeiro de 2020).

Lima Filho, O.F., 2013. O silício e a resistência das plantas ao ataque de fungos patogênicos. http://www.cpao.embrapa.br/portal/artigos/artigos/artigo1.htm 1 (acessado 11 de agosto de 2020). 
Malavolta, E., Vitti, G.C., Oliveira, S.A., 1997. Avaliação do estado nutricional das plantas: princípios e aplicações. Piracicaba, Potafos. DOI https://www.bdpa.cnptia.embrapa.br/consulta/busca?b=ad\&id $=559727 \&$ biblioteca $=$ CPACT\&busca $=$ autoria: $\% 22 \mathrm{MALAVO}$ LTA, \%20E.\%22\&qFacets=autoria:\%22MALAVOLTA, \%20E .$\% 22 \&$ sort $=\&$ paginacao $=t \&$ paginaAtual $=1$.

Marschner, H., 1995. Mineral nutrition of higher plants. London, Academic Press. DOI: https://doi.org/10.1006/anbo.1996.0155.

Miranda, P.S., Santos, J.R.E., Moraes, T.R., Maluf, R.P., 2018. Efeito do silício no cultivo e pós-colheita do repolho. Revista Brasileira de Agroecologia, 13(2), 30-35. DOI: http://revistas.aba-

agroecologia.org.br/index.php/rbagroecologia/article/view/208 98.

Pará, 2012. Inventário da oferta turística: Parauapebas. http://www.setur.pa.gov.br/sites/default/files/pdf/inventario_p arauapebas_0.pdf (acessado 12 de dezembro de 2019).

Pohlmann, V., Santos, B.T.D., Knies, A.E., Ludwig, F., 2018. Adubação foliar silicatada na cultura da rúcula. Revista Cultivando o Saber, 11(4), 424-434. DOI: https://www.fag.edu.br/upload/revista/cultivando_o_saber/5c0 6b7a86a9d3.pdf.

Resende, G.M., Yuri, J.E., Mota, J.H., Freitas, S.A.C., Rodrigues, J.C., Souza, R.J., Carvalho, J.G., 2003. Adubação foliar com silício em alface americana (Lactuca sativa L.) em cultivo de verão. Horticultura Brasileira, 21(2), 374-377. DOI: https://www.embrapa.br/busca-de-publicacoes//publicacao/153950/adubacao-foliar-com-silicio-em-alfaceamericana-lactuca-sativa-l-em-cultivo-de-verao.

Sala, F.C., Costa, C.P., 2012. Retrospectiva e tendência da alfacicultura brasileira. Horticultura Brasileira, 30(2), 187-194. DOI: https://doi.org/10.1590/S0102-05362012000200002.

Santos, H.G., Jacomine, P.K.T., Anjos, L.H.C., Oliveira, V.A., Lumbreras, J.F., Almeida, J.A., Coelho, M.R., Almeida, J.A., Cunha, T.J.F., Oliveira, J.B., 2013. Sistema brasileiro de classificação de solos, terceira ed. Brasília, Embrapa. DOI: https://livimagens.sct.embrapa.br/amostras/00053080.pdf.

Souza, R.S., Rezende, R., Freitas, P.S.L., Gonçalves, A.C.A., Rezende, G.S., 2015. Dry matter production and macronutrient leaf composition in lettuce under fertigation with nitrogen, potassium and silicon. Revista Brasileira de Engenharia Agrícola e Ambiental, 19(12), 1166-1171. DOI: https://doi.org/10.1590/1807-1929/agriambi.v19n12p11661171.

Sripanyakorn, S., Jugdaohsingh, R., Thompson, R.P.H., Powell, J.J., 2005. Dietary silicon and bone health. Nutrition Bulletin, London, 30(3), 222-230. DOI: https://doi.org/10.1111/j.1467-3010.2005.00507.x.

Taiz, L., Zeig, E., Møller, I.M., Murphy, A., 2015. Plant physiology and development, sixth ed. Sinauer Associates, Sunderland. DOI: http://6e.plantphys.net/.

Takahashi, N., Kurata, K., 2007. Relationship between transpiration and silica content of the rice panicle under elevated atmospheric carbon dioxide concentration. Journal of Agricultural Meteorology, 63(2), 89-94. DOI: 10.2480/agrmet.63.89.

Yoshida, S., 1975. The physiology of silicon in rice. Taipei: Food and Fertilization Technology Center. (FFTC. Technical Bulletin, 25). DOI: https://catalogue.nla.gov.au/Record/4555774.

Yuri, J.E., Mota, J.H., Resende, G.M., Souza, R.J., 2016. Nutrição e adubação da cultura da alface, in: Prado, R.M., Cecílio Filho, A.B., (Ed.). Nutrição e adubação de hortaliças. Jaboticabal, FCAV/UNESP, p. 559-577. DOI: https://www.embrapa.br/busca-de-publicacoes//publicacao/1044447/nutricao-e-adubacao-da-cultura-daalface.

Zanão Júnior, L.A.Z., Alvarez, V.H., Zanão, M.P.C., Fontes, R.L.F., Grossi, J.A.S., 2013. Produção de rosas influenciada pela aplicação de silício no substrato. Revista Brasileira de Ciência do Solo, 37(6), 1611-1619. DOI: https://doi.org/10.1590/S0100-06832013000600017. 